\title{
DETERMINAN KELUHAN KONJUNGTIVITIS PADA PEKERJA LAS DI KECAMATAN JELUTUNG KOTA JAMBI
}

\author{
Determinants of Welding Workers Conjunctivitis Complaints in Jelutung District Jambi \\ City
}

\author{
Siti Suherni ${ }^{1}$, Muhammad Syukri ${ }^{1}$, Dwi Noerjoedianto ${ }^{1}$, Budi Aswin ${ }^{1}$ \\ ${ }^{1}$ Jurusan Kesehatan Masyarakat, Fakultas Kedokteran dan Ilmu Kesehatan Universitas Jambi
}

\begin{abstract}
ABSTRAK
Konjungtivitis merupakan peradangan pada konjungtiva yang disebabkan oleh sinar ultraviolet yang berasal dari proses pengelasan. Penelitian ini bertujuan untuk mengetahui faktor-faktor apa saja yang berhubungan dengan keluhan konjungtivitis pada pekerja Bengkel Las Kecamatan Jelutung Kota Jambi. Penelitian ini menggunakan desain cross-sectional pada 53 pekerja las di Wilayah Kecamatan Jelutung Kota Jambi pada bulan September-Oktober 2020. Pengambilan sampel menggunakan teknik proportional random sampling. Analisis data dilakukan menggunakan uji Chi-Square. Hasil analisis menunjukkan dari 53 responden terdapat 28 orang $(52,8 \%)$ dengan keluhan konjungtivitis. Hasil analisis Chi-square menunjukkan adanya hubungan bermakna masa kerja (P-Value 0.009), lama paparan (P-Value 0,007) dengan keluhan konjungtivitis. Variabel yang tidak berhubungan dengan keluhan konjungtivitas adalah penggunaan APD (P-Value 0,0758). Kesimpulan dari penelitian ini adalah terdapat hubungan antara masa kerja, lama paparan dengan keluhan konjungtivitis pada pekerja bengkel las Kecamatan Jelutung Kota Jambi.
\end{abstract}

Kata Kunci : Masa kerja, Lama paparan, pekerja las, konjungtivitis,

\begin{abstract}
Conjunctivitis is an inflammation of the conjunctiva caused by ultraviolet light from the welding process. This study aimed to determine factors associated with complaints of conjunctivitis in welding workers. Cross-sectional design was applied to this study with 53 welding workers in the Jelutung District, Jambi City taken from September-October 2020. Samples were collected using a proportional random sampling technique. Data analysis was performed using the Chi-Square test. The results showed that from 53 respondents there were 28 people $(52.8 \%)$ with complaints of conjunctivitis. The results of the Chi-square analysis showed that there was a significant relationship between work period (P-Value 0.009), length of exposure (P-Value 0.007) with complaints of conjunctivitis. The variable not related to conjunctivitis complaints was the use of personal protective equipment (P-Value 0.0758). This study concluded work period, length of exposure associated with the complaints of conjunctivitis in welding workshop workers in Jelutung District, Jambi City.
\end{abstract}

Keywords : Work period, length of exposure, welding workers, conjunctivitis

$\begin{array}{ll}\text { Korespondensi } & : \text { Muhammad Syukri } \\ \text { Email } & : \text { syukri.muhammad@unja.ac.id }\end{array}$




\section{PENDAHULUAN}

Perkembangan dunia kerja pada sektor informal saat ini lebih cepat dibanding sektor formal. Berdasarkan data Badan Pusat Statistik (BPS) dari 136,18 juta pekerja di Indonesia, lebih dari 74,08 juta orang bekerja di sektor informal.(1) Sektor Informal adalah aktivitas ekonomi individu dengan skala kecil, tidak terorganisasi yang lahir sebagai reaksi terhadap kegiatan ekonomi skala besar dan terorganisasi.(2) Sektor informal memiliki pola kerja yang tidak teratur, baik dari aspek waktu, kapital, penerimaan, dan belum banyak tersentuh oleh peraturan yang telah ditetapkan.(3) Salah satu pekerjaan yang bergerak dalam sektor informal yaitu pengelasan.(4) Pengelasan merupakan teknik menghubungkan dua benda dengan cara dididihkan. Sebagai bahan pengisi dibutuhkan tenaga panas dalam mengencerkan bahan bakar yang akan dihubungkan dari kawat las. Membentuk sambungan yang kuat dan permanen dengan menunggu pemanasan menjadi api dan pecahan logam berupa partikel pada saat menyatukan logam.(5)

Banyak jenis pekerjaan yang rentan mengalami kecelakaan dan bahaya kerja, salah satunya adalah pekerja las.(6) Pekerja las bisa terpapar radiasi sinar las pada saat proses pengelasan.(7) Salah satu radiasi sinar las yang dihasilkan selama proses pengelasan adalah radiasi sinar ultraviolet dengan gelombang 240-320 nm. Mata merupakan bagian tubuh yang sangat peka oleh sinar ultraviolet.(8) Pemaparan ultraviolet pada mata dapat menyebabkan peradangan pada kornea dan selaput mata konjungtivitis.(9)

Konjungtivitis merupakan penyakit mata merah yang dapat menular secara cepat. Konjungtivitis dapat disebabkan oleh virus, bakteri, dan alergi.(10) Terpaparnya mata pekerja akibat sinar maupun asap yang berasal dari pekerjaan las dapat berkaitan dengan masa kerja.(11) Menurut Harahap (2013) masa kerja memiliki hubungan dengan konjungtivitis.(12) Lamanya seseorang bekerja, maka bertambah bahaya pajanan sinar maupun asap terhadap mata. Akan tetapi waktu kerja juga memiliki pengaruh positif terhadap pekerja dalam mengantisipasi bahaya apa saja yang bersumber dari pekerjaan yang dilakoninya. Hal-hal negatif yang pernah dirasakan menjadi pemicu agar berhati-hati dalam bekerja sehingga meminimalisir melakukan kesalahan berulang.(11) Menurut hierarki pengendalian risiko, alat pelindung diri merupakan sistem perlindungan terakhir.(13) Alat pelindung diri memiliki pengaruh terhadap munculnya keluhan konjungtivitis.(9) Hal ini diperkuat hasil penelitian Herdianti (2017) yang menyimpulkan adanya hubungan penggunaan alat pelindung diri dengan keluhan konjungtivitis pada pekerja las industri kecil.(14)

Berdasarkan laporan Dinas

Perindustrian dan Perdagangan Kota Jambi, pada tahun 2019 terdapat 101 bengkel las pada 5 Kecamatan di Kota Jambi. Kecamatan Jelutung merupakan kecamatan yang memiliki jumlah pekerja bengkel las terbanyak yaitu 120 orang dari 13 bengkel las di Kota Jambi. Hasil survei awal yang dilakukan di Bengkel Las Wilayah Kecamatan Jelutung Kota Jambi, dari 10 pekerja yang diwawancarai terdapat 6 pekerja yang mengeluh mengalami konjungtivitas. Beberapa keluhan yang dilaporkan adalah rasa perih yang muncul pada mata hingga menyebabkan keluarnya air mata dalam jumlah yang cukup banyak. Selain itu gejala lainnya berupa rasa gatal 
pada mata seperti terdapat material yang masuk ke dalam mata, rasa silau dan panas seolah terbakar.

Berdasarkan hal tersebut, peneliti tertarik untuk mengetahui hubungan masa kerja, lama paparan dan penggunaan Alat Pelindung Diri dengan keluhan konjungtivitis pada pekerja bengkel las di Kecamatan Jelutung Kota Jambi Tahun 2020.

\section{METODE}

Penelitian ini adalah penelitian kuantitatif dengan rancangan cross-sectional yang dilakukan pada bulan
September-Oktober 2020. Populasi dalam penelitian ini adalah seluruh bengkel las di Kecamatan Jelutung Kota Jambi yang berjumlah 13 bengkel las dengan jumlah pekerja 120 orang. Pengambilan sampel dilakukan dengan cara proportional random sampling dengan jumlah sebanyak 53 responden. Data keluhan konjungtivitis, masa kerja, dan lama paparan diperoleh melalui lembar kuesioner. Sedangkan data penggunaan Alat Pelindung Diri diperoleh melalui lembar observasi. Pengolahan data dilakukan secara univariat, dan bivariat menggunakan uji chi-square dengan perangkat lunak SPSS 16.0

\section{HASIL}

Tabel 1. Distribusi Karakteristik Umum Responden

\begin{tabular}{lrr}
\multicolumn{1}{c}{ Karakteristik Responden } & $\begin{array}{c}\text { Frekuensi } \\
(\mathbf{n = 5 3 )}\end{array}$ & Porsentase (\%) \\
\hline Pendidikan Responden & 1 & 1,9 \\
SD/ Sederajat & 13 & 24,5 \\
SMP/ Sederajat & 38 & 71,7 \\
SMA/ Sederajat & 1 & 1,9 \\
PT & & 26,4 \\
Umur Responden (tahun) & 14 & 35,8 \\
15-30 & 19 & 32,1 \\
31-45 & 17 & 5,7 \\
46-60 & 3 & \\
61-75 & 3 & \\
\hline
\end{tabular}

Sumber: Data Primer, 2020

Tabel 1 di atas menjunjukkan dominan responden berada pada rentang umur 31-45 tahun sebanyak 19 orang $(35,8 \%)$, dan paling sedikit adalah responden yang berada pada kelompok umur 61-75 tahun. Tingkat pendidikan responden paling banyak SMA/sederajat yaitu sebanyak 38 orang atau sebesar $71,7 \%$ dan paling sedikit berpendidikan $\mathrm{SD} /$ sederajat sebanyak 1 orang dengan persentase $1,9 \%$.
Tabel 2 di bawah memperlihatkan lebih dari setengah responden penelitian mengeluh mengalami konjungtivis yaitu sebanyak 28 subjek (52,8\%). Responden dengan masa kerja kategori lama sebanyak 28 (52,8\%), dan umumnya responden mengalami paparan kategori berisiko sebanyak $38(71,7 \%)$. Sedangkan pada kategori alat pelindung diri, sebagian besar terdapat pada alat pelindung diri kategori tidak berisiko sebanyak 34 (64,2\%). 
Tabel 2. Distribusi Frekuensi Variabel Penelitian

\begin{tabular}{lcr}
\hline \multicolumn{1}{c}{ Variabel } & $\begin{array}{c}\text { Frekuensi } \\
(\mathbf{n = 5 3 )}\end{array}$ & Porsentase (\%) \\
\hline Keluhan Knjungtivitis & 28 & 52,8 \\
Ada keluhan & 25 & 47,2 \\
Tidak ada keluhan & & \\
Masa Kerja & 28 & 52,8 \\
$\quad$ Lama ( $\geq 5$ Tahun) & 25 & 47,2 \\
Baru (<5 Tahun) & & \\
Lama Paparan & 38 & 71,7 \\
Berisiko ( $\geq 2$ jam/hari) & 15 & 28,3 \\
Tidak Berisiko(<2jam/hari) & & \\
Alat Pelindung Diri & 19 & 35,8 \\
Berisiko & 34 & 64,2 \\
Tidak Berisiko & &
\end{tabular}

Sumber: Data Primer, 2020

Tabel 3. Hubungan Variabel Masa Kerja, Lama Paparan, Penggunaan Alat Pelindung Diri dengan Keluhan Konjungtivitis

\begin{tabular}{|c|c|c|c|c|c|c|}
\hline \multirow{3}{*}{ Variabel } & \multicolumn{4}{|c|}{ Keluhan Konjungtivitis } & \multirow{3}{*}{ PR (95\%CI) } & \multirow{3}{*}{$P$ Value } \\
\hline & \multicolumn{2}{|c|}{ Ada keluhan } & \multicolumn{2}{|c|}{$\begin{array}{c}\text { Tidak ada } \\
\text { keluhan }\end{array}$} & & \\
\hline & n (28) & $\%$ & n (25) & $\%$ & & \\
\hline \multicolumn{7}{|l|}{ Masa kerja } \\
\hline Lama ( $\geq 5$ tahun) & 20 & 71,4 & 8 & 28,6 & $2,23(1,20-4,13)$ & 0,009 \\
\hline Baru $(<5$ tahun $)$ & 8 & 32,0 & 17 & 68,0 & & \\
\hline \multicolumn{7}{|l|}{ Lama paparan } \\
\hline$\geq 2$ jam per hari & 25 & 65,8 & 13 & 34,2 & $3,28(1,16-9,28)$ & 0,007 \\
\hline$<2$ jam per hari & 3 & 20,0 & 12 & 80,0 & & \\
\hline \multicolumn{7}{|l|}{ Penggunaan APD } \\
\hline Berisiko & 9 & 47,4 & 10 & 52,6 & $0,84(0,48-1,48)$ & 0,758 \\
\hline Tidak berisiko & 19 & 55,9 & 15 & 44,1 & & \\
\hline
\end{tabular}

Sumber: Data Primer, 2020

Berdasarkan Tabel 3 di atas dapat disimpulkan variabel masa kerja berhubungan dengan keluhan konjungtivitas dengan nilai p 0,009 dengan nilai PR sebesar 2,23 yang artinya responden dengan massa kerja lama memiliki risiko 2,232 kali untuk mengalami keluhan konjungtivitis dibandingkan responden dengan masa kerja baru. Pada variabel lama paparan diperoleh nilai p-Value 0,007 dengan nilai PR sebesar 3,28 sehingga dapat disimpulkan bahwa adanya hubungan antara lama paparan dengan keluhan konjungtivitis dengan responden yang mengalami lama paparan memilikirisiko 3,289 kali untuk mengalami keluhan konjungtivitis. Variabel alat pelindung diri diperoleh nilai $\mathrm{p}$-Value 0,0758 yang berarti tidak ada hubungan penggunaan alat pelindung diri dengan keluhan konjungtivitis.

\section{PEMBAHASAN}

Temuin studi ini menunjukkan bahwa keluhan konjungtivis pada pekerja las di Kecamatan Jelutung Kota Jambi masih tinggi (52,8\%). Penemuan ini memperkuat hasil studi sebelumnya yang menemukan masih tingginya keluhan 
konjungtivitis pada pekerja las. $(14,15)$ Konjungtivitis merupakan hal yang umum terjadi, disebabkan letakkonjungtiva mudah terpapar agen penyakit, dan faktor lain berbasis lingkungan.(16) beberapa faktor yang berhubungan dengan keluhan konjungtivis pada pekerja las, antara lain masa kerja, durasi kerja, dan penggunaan Alat Pelindung Diri (APD). Penelitian ini menemukan adanya hubungan masa kerja dengan keluhan konjungtivitis dengan proporsi keluhan konjungtivitis pada pekerja dengan masa kerja lama adalah $71,4 \%$. Pekerja dengan masa kerja $\geq 5$ tahun memiliki risiko2,23 kali mengeluh konjungtivis dibanding pekerja dengan masa kerja $<5$ tahun. Studi ini mendukung penelitian sebelumnya yang juga menunjukkan adanya hubungan masa kerja dengan keluhan konjungtivis pada pekerja las. $(4,12)$ Kesehatan mata pada pekerja las dipengaruhi oleh seberapa lama pekerja melakukan kegiatan las. Semakin tinggi jam terbang seorang pekerja, maka semakin besar pula risiko mengalami gangguan kesehatan matanya.(15) Berdasarkan hasil temuan lapangan, diketahui bahwa para pekerja las seringkali mengalami keluhan pada mata atau konjungtivitis saat melakukan pekerjaan, terutama bagi pekerja yang memiliki masa kerja lebih lama. Keluhan mata yang dialami oleh para pekerja tersebut dianggap sebagai hal yang lumrah dan tidak serius, sehingga membuat mereka merasa terbiasa dengan paparan sinar selama proses pengelasan dan merasa tidak perlu untuk menggunakan APD karena efek yang timbul dari pekerjaan yang mereka lakukan telah terjadi dalam waktu yang lama dan dianggap tidak berbahaya. Sebaliknya, pekerja las yang tergolong baru atau dengan masa kerja yang relatif tidak lama cenderung lebih taat dan peduli terhadap kesehatan, sehingga mereka lebih patuh dalam menggunakan APD untuk menghindari atau mengurangi paparan yang muncul akibat pekerjaan yang mereka lakukan. Oleh karena itu pekerja dengan masa kerja yang tergolong baru, lebih dapat terhindar dari keluhan mata akibat proses pengelasan yang mereka kerjakan dan keluhan konjungtivitis lebih banyak terjadi pada pekerja dengan masa kerja yang lebih lama.

Studi ini juga menemukan adannya hubungan lama paparan dengan keluhan konjungtivitis dengan lama paparan $\geq 2$ jam/hari memiliki risiko 3,289 kali lebih besar untuk mengalami keluhan konjungtivitis dibandingkan pekerja dengan lama paparan $<2$ jam/hari . Hasil penelitian ini memperkuat studi yang dilakukan Ramdan, dkk (2017) di Samarinda Utara tentang gejala konjungtivitis pada operator las yang menunjukkan adanya hubungan lama paparan dengan keluhan konjungtivitis.(14,17)' Hal yang sama juga yang ditemukan Ramdan, dkk (2017) yang menyimpulkan durasi paparan sinar UV berhubungan erat dengan konjungtivitis.(18) Beratnya pegaruh paparan sinar UV dari pengelasan tergantung pada banyak faktor, salah satunya durasi paparan. Flash burn merupakan salah satu dampak yang terjadi akibat lama paparan radiasi UV. Penelitian yang dilakukan di Taiwan pekerja yang terpapar selama 41,1 menit, 16,9 menit dan 1 detik memiliki beda rata-rata dengan kejadian photokeratokonjungtivitis.(19) Keluhan konjungtivitis akan terasa lebih dari dua jam terpapar. Dampak paparan akan semakin parah seiring semakin lama pekerja terpapar sinar UV yang menyebabkan banyaknya jaringan yang rusak.(16) 
Alat pelindung diri, biasa disebut sebagai APD adalah peralatan yang dipakai untuk meminimalkan paparan bahaya yang menyebabkan cedera dan penyakit serius di tempat kerja. Cedera dan penyakit ini dapat terjadi akibat kontak dengan bahaya kimiawi, radiologis, fisik, listrik, mekanis, atau tempat kerja lainnya.(20) Hasil penelitian menunjukkan tidak ada hubungan penggunaan alat pelindung diri dengan keluhan konjungtivitis. Penelitian ini tidak memperkuat temuan yang dilakukan Harahap, dkk (2017), Ramdan, dkk (2017), dan Pratiwi, dkk (2015) yang menemukan adanya hubungan penggunaan APD dengan keluhan konjungtivis.(11,12,17) Namun studi ini sejalan dengan penelitian yang dilakukan Wahyuni (2013) di Kecamatan Cilacap Tengah Kabupaten Cilacap yang menunjukkan bahwa tidak ada hubungan antara APD dengan keluhan konjungtivitis pada pekerja.(21) Untuk melindungi dalam bekerja, tentunya seseorang membutuhkan alat yang dapat melindungi dirinya dari bahaya atau kecelakaan di tempat kerja. APD tidak berhubungan dengan keluhan konjungtivitis dikarenakan sebagian besar yang tidak menggunakan APD tanpa disertai keluhan kemungkinan masa kerja $<5$ tahun dan durasi paparan tidak terlalu lama. Selain itu, proporsi subjek yang tidak menggunakan APD rendah sehingga diperlukan penelitian dengan jumlah sampel yang besar untuk membuktikan ada atau tidaknya hubungan dengan keluhan konjungtivitis. Penelitian ini menggunakan desain cross-sectional sehingga sulit dimana pada desain penelitian ini pengambilan data variabel bebas dan terikat dilakukan secara sewaktu dan tidak bisa memperoleh hubungan kausalitas (sebab akibat) secara jelas.

\section{KESIMPULAN DAN SARAN}

Proporsi keluhan konjungtivitis pada pekerja bengkel las Kecamatan Jelutung menunjukkan angka sebesar $52,8 \%$. Terdapat hubungan antara masa kerja, lama paparan dengan keluhan konjungtivitis pada pekerja bengkel las Kecamatan Jelutung Kota Jambi. Tidak ada hubungan antara penggunaan alat pelindung diri dengan keluhan konjungtivitis pada pekerja bengkel las Kecamatan Jelutung Kota Jambi. Diharapkan agar kepada pekerja las agar memperhatikan lama kerja sehingga bisa mengurangi terjadinya keluhan konjungtivitis.

\section{DAFTAR PUSTAKA}

1. Badan Pusat Statistik Indonesia. Keadaan Angkatan Kerja di Indonesia [Internet]. Vol. 1. Jakarta; 2018 Nov. Available from: https://www.bps.go.id/publication/2018/1 1/30/6d8a8eb26ac657f7bd170fca/keadaan -angkatan-kerja-di-indonesia-agustus-201 8.html

2. Chrismardani Y-, Satriawan B. TENAGA KERJA SEKTOR FORMAL DAN INFORMAL DI KABUPATEN BANGKALAN. Media Trend [Internet]. 2018 Apr 24;13(1):158. Available from: http://journal.trunojoyo.ac.id/mediatrend/ article/view/3665

3. Nurhayati SF. Analisis Kondisi Sosial Ekonomi, Kendala dan Peluang Usaha Pedagang Kaki Lima: Studi pada Pedagang Kaki Lima di Seputar Alun-Alun Kabupaten Klaten. Semin Nas Ris Manaj Bisnis 2017 "Perkembangan Konsep dan $\mathrm{R}$ iset E-bus di Indones [Internet]. 2017;828-43. Available from: https://publikasiilmiah.ums.ac.id/bitstrea m/handle/11617/8990/sansetmab2017_11 .pdf? sequence $=1 \&$ isAllowed $=\mathrm{y}$

4. Yuda NAP. Faktor Risiko yang Berhubungan dengan Keluhan Fotokeratitis pada Pekerja Pengelasan. Medula. 2018;8(1):117-21.

5. Wiryosumarto $\mathrm{H}$. Teknologi Pengelasan Logam. Jakarta: Balai Pustaka; 2014.

6. Husaini H, Setyaningrum R, Saputra M. FAKTOR PENYEBAB PENYAKIT AKIBAT KERJA PADA PEKERJA LAS. Media Kesehat Masy Indones [Internet]. 
2017 Mar 29;13(1 SE-):73-9. Available from:

https://journal.unhas.ac.id/index.php/mk $\mathrm{mi} /$ article/view/1583

7. Qolik A, Yoto Y, Basuki B, Sunomo S, Wahono W. Bahaya Asap dan Radiasi Sinar Las Terhadap Pekerja Las di Sektor Informal. J Tek Mesin dan Pembelajaran. 2018;1(1):1.

8. Kurniawan A. GEJALA FOTOKERATITIS AKUT AKIBAT RADIASI SINAR ULTRAVIOLET (UV) PADA PEKERJA LAS DI PT. PAL INDONESIA SURABAYA. IKESMA [Internet]. 2017 Mar 16;13(1):22-31. Available from: https://jurnal.unej.ac.id/index.php/IKESM A/article/view/7021

9. Dewi A. Dasar-Dasar Keselamatan dan Kesehatan Kerja [Internet]. Jember: UPT Penerbitan UNEJ; 2012. Available from: http://penerbitan.unej.ac.id/wp-content/up loads/2018/11/dasar-dasar-keselamatan-d an-kesehatan-kerja.pdf

10. Irianto K. Anatomi dan Fisiologi (Edisi Revisi). Edisi Revi. Bandung: Alfabeta; 2017.

11. Pratiwi YS, Widada W, A. ZEY. Gangguan Kesehatan Mata Pada Pekerja Di Bengkel Las Listrik Desa Sempolan, Kecamatan Silo, Kabupaten Jember. Indones J Heal Sci. 2015;5(2):137-49.

12. Harahap PS, Rachman I, Simanjuntak F. Faktor-Faktor yang Berhubungan dengan Keluhan Mata pada Pekerja Las Industri Kecil di Kecamatan Tungkal Ilir Kabupaten Tanjab Barat Tahun 2017. Ris Inf Kesehat [Internet]. 2017 Dec 29;6(2):142. Available from: http://www.stikes-hi.ac.id/jurnal/index.ph p/rik/article/view/http\%3A\%2F\%2Fwww .stikes-hi.ac.id\%2Fjurnal\%2Findex.php\% 2Frik\%2Farticle $\% 2$ Fview $\% 2$ F104\%2F36

13. OHSS. Occupational Health and Safety Management System - Requirements. 2007.

14. Herdianti Entianopa; Anastasia, Amanda Puspita HE. FAKTOR YANG BERHUBUNGAN DENGAN KELUHAN KONJUNGTIVITIS PADA PEKERJA BENGKEL LAS WILAYAH SIMPANG KAWAT KOTA JAMBI TAHUN 2017. J Ilm Ilmu Kesehat Wawasan Kesehat [Internet]. 2018;(Vol 5, No 1 (2018): JULI 2018). Available from: http://journal.stikes-kapuasraya.ac.id/inde x.php/JIIK-WK/article/view/95

15. Ibrahim; Nurul Widiati. HUBUNGAN
LAMA TERPAPAR SINAR LAS DENGAN KEJADIAN KONJUNGTIVITIS FOTOELEKTRIK DI PT. BINTANG INTI PERSADA SHIPYARD BATAM. Zo Kedokt [Internet]. 2019;9(3):82-91. Available from:

http://ejurnal.univbatam.ac.id/index.php/z onadokter/article/view/305

16. Watson S, Cabrera-Aguas $\mathrm{M}$, Khoo P. Common eye infections. Aust Prescr. 2018;41(3):67-72.

17. Ramdan IM, Mursyidah SB, Jubaedah S. Photokeratoconjunctivitis Symptoms among Informal Welding Operators in North Samarinda, Indonesia. Glob Med Heal Commun. 2017;5(2):144.

18. ARSANJANI. FAKTOR YANG BERHUBUNGAN DENGAN KEJADIAN SINDROM PHOTOKERATITIS PADA PEKERJA LAS LISTRIK DI KELURAHAN ROMANG POLONG KECAMATAN SOMBA OPU KABUPATEN GOWA [Internet]. FAKULTAS KEDOKTERAN DAN ILMU KESEHATAN UNIVERSITAS ISLAM NEGERI ALAUDDIN MAKASSAR. FAKULTAS KEDOKTERAN DAN ILMU KESEHATAN UNIVERSITAS ISLAM NEGERI ALAUDDIN; 2017. Available from:

http://repositori.uin-alauddin.ac.id/8141/1 /ARSANJANI.pdf

19. Kuo Y-K, Lin I-C, Chien L-N, Lin T-Y, How Y-T, Chen K-H, et al. Dry Eye Disease: A Review of Epidemiology in Taiwan, and its Clinical Treatment and Merits. J Clin Med. 2019;8(8):1227.

20. United States Department of Labor. Personal Protective Equipment [Internet]. 2020 [cited 2020 Nov 21]. Available from: https://www.osha.gov/personal-protective -equipment

21. Wahyuni T. Faktor Risiko Yang Berhubungan Dengan Kejadian Konjungtivitis Pada Pekerja Pengelasan Di Kecamatan Cilacap Tengah Kabupaten Cilacap. J Kesehat Masy Univ Diponegoro [Internet]. 2013;2(1):18-25. Available from:

https://media.neliti.com/media/publicatio ns/18761-ID-faktor-risiko-yang-berhubun gan-dengan-kejadian-konjungtivitis-padapekerja-penge.pdf 